\title{
Deprovincializing European universities
}

Déprovincialiser les universités européennes

Desprovincializar las universidades europeas

\section{Caroline Rolland-Diamond, Capucine Boidin, James Cohen and Ramon Grosfoguel}

\section{(2) OpenEdition}

\section{Journals}

Electronic version

URL: https://journals.openedition.org/ideas/2292

DOI: 10.4000/ideas.2292

ISSN: 1950-5701

This article is a translation of:

Déprovincialiser les universités européennes - URL : https://journals.openedition.org/ideas/278 [fr]

Other translation(s):

Desprovincializar as universidades europeias - URL : https://journals.openedition.org/ideas/3048 [pt] Desprovincializar las universidades europeas - URL : https://journals.openedition.org/ideas/3053 [es]

\section{Publisher}

Institut des Amériques

Electronic reference

Caroline Rolland-Diamond, Capucine Boidin, James Cohen and Ramon Grosfoguel, "Deprovincializing European universities", IdeAs [Online], 2 | 2012, Online since 11 June 2012, connection on 19 October 2022. URL: http://journals.openedition.org/ideas/2292 ; DOI: https://doi.org/10.4000/ideas.2292

This text was automatically generated on 19 October 2022

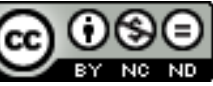

Creative Commons - Attribution-NonCommercial-NoDerivatives 4.0 International - CC BY-NC-ND 4.0

https://creativecommons.org/licenses/by-nc-nd/4.0/ 


\title{
Deprovincializing European universities
}

\author{
Déprovincialiser les universités européennes \\ Desprovincializar las universidades europeas
}

Caroline Rolland-Diamond, Capucine Boidin, James Cohen and Ramon

Grosfoguel

\section{European universities at a crossroads}

1 The Shanghai rating published in 2003 was a severe blow to France's pride, as it relegated French universities and grandes écoles to the bottom of the honorific ladder, far behind North American, British, and Japanese universities. This ranking gave rise to a great amount of criticism, probably the most important of which concerned the comparative advantage that publications in English benefit from in a context of international competition, along with the difficult hierarchization of universities in the field of human and social sciences. However, the up-to-date analysis of several world rankings conducted by Hervé Théry for our "Eclairages" section invites us to reexamine our views on this issue: "Regarding the four retained ratings, the concentration of top ranking universities in certain regions of the world is so important that three close-ups were added to the planisphere in order to provide a more detailed account of the situation in the United States, Europe, and Japan." This collection of articles encourages French-speaking readers to broaden the scope of their preoccupations from the question of the "declension" or "incomparability" of the French model to the issue of world inequalities, ${ }^{1}$ and more specifically the imbalance between North and South American universities, even though certain Brazilian, Mexican, Argentinian, and Chilean universities do appear in some ratings. ${ }^{2}$

Ratings should be dosed out as salt - without either using them too massively or banning them altogether -, as expressed by Boaventura de Sousa, whose reflections and propositions for European universities may be found in the "Eclairages" section of this issue. This collection of articles seeks to reflect upon the situation of European 
universities in the light of American experiences. The influence of the American academic model was first felt in Latin America before it reached Europe. The liberalization of the higher education market, the multiplication of evaluation agencies, along with the creation of specialized academic institutions for certain minority groups were already implemented in Latin America as early as the 1990s. Regarding such issues, Manuela Boatca's article shows how "excellence initiatives" are being carried out in Germany as a way of catching up with new Western standards and the American higher education model. The feeling of having to "catch up" with this model is widely felt within the European academic system, even though the first impulse that gave rise to the creation of this common space of higher education had entirely different roots.

\section{Advertisement for Uninorte, in Asunción}

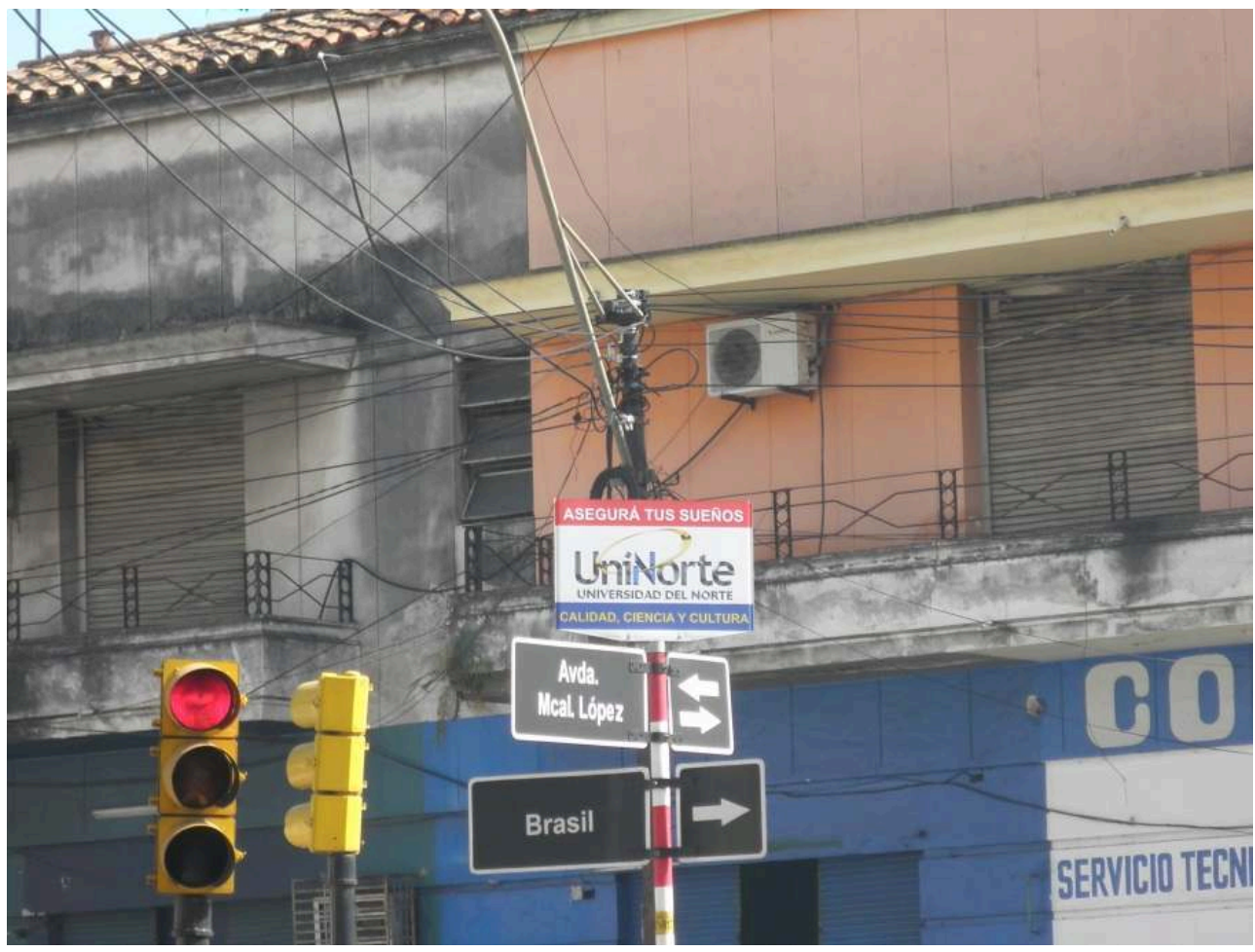

An omnipresent advertisement in the city of Asunción for UNINORTE, a private university: 'Make sure you realize your dreams,' UniNorte, Quality, Science and Culture. The imperative is accentuated by the Paraguayan pronunciation, influenced by the Guarani language: "Asegurà"

Foto: C. Boidin, Paraguay, 2011

3 The project of creating a European space for higher education was launched at the Sorbonne in 1998: "The kind of Europe we are building is not only that of the Euro, banks and, the economy; it must also become a Europe of knowledge." This process was officially launched in Bologna in 1999 with 29 signatory countries. However, the Bologna declaration included an objective that was nowhere mentioned in 1998: "European cooperation in quality assurance." What do these two words - "assurance" and "quality" - mean when brought together? "In higher education, quality assurance refers to all the policies, processes and practices designed to ensure the upholding or improvement of quality standards defined in a specific context." ${ }^{4}$ In such a system, the autonomy and financial liability of universities, along with their external evaluation, are the main criteria ensuring potential partners and collaborators of the quality of these universities. The creation of EQAR (European Quality Assurance Register) in 2007 
triggered off the creation of a number of national structures for the quality assessment in universities: the AERES (Agence d'Evaluation de l'Enseignement et de la Recherche) in France, for example.

Universities were then conceived so as to be run in the same way as business organizations, through such means as benchmarking - the setting of short-term quantifiable objectives -, a method analyzed by Isabelle Bruno, ${ }^{5}$ and by which individuals and organizations are compelled to fulfill those objectives at all costs and are thus put in competition with one another. The financing of "excellence initiatives" - or, to put it more clearly, the "targeted" financing of programs and institutions partakes of this logic of competition. Consequently, all cooperation may become arduous and complex to organize, and any kind of profound reflection impossible to carry out, as the run for funds, meeting targets, and constant reporting tend to monopolize a lot of thetime and energy spent in higher education institutions. Boaventura de Sousa sums it up well:

"In a few decades the university went from producing knowledge and professionals for the market, to becoming itself a market, the market of tertiary education, and finally, at least according to powerful visionaries, to being run like a market organization, a business organization."

5 The second and last major objective added to the initial project defined at the Sorbonne - concerning "the social dimension of higher education" - was not precisely defined until the 2007 London Communiqué, according to which "the student body entering, participating in, and completing higher education at all levels should reflect the diversity of our populations." ${ }^{\text {"With }}$ respect to the current governance criteria based on quantifiable objectives, the 2010 assessment turned out more mitigated regarding such issues than concerning the creation of a common frame of reference ${ }^{7}$ and the implementation of quality assurance:

"Very few countries have yet defined any specific quantifiable objectives to increase the level of participation of the minority groups still under-represented in higher education institutions, and only half of the Bologna countries carry out the systematic control of the latter's participation in such institutions. The most frequently adopted national measures meant to increase this participation consist in the creation of targeted financial aid programs and parallel curriculums and/or admission procedures. (...) In the signatory countries of the Bologna declaration, under-representation is most often linked to the socio-economic background and level of schooling of parents, and to a minority status or handicap. (...) The various approaches to the identification of under-represented groups show the often complex and intricate nature of this issue, which rules out any kind of practical Pan-European comparison." (our italics)

6 In other words, members of certain defined categories are being allocated targeted financial aids that will enable them to enter a number of elite institutions susceptible of being competitive at the international level. Paradoxically, this policy also leads to the reduction of the investments spent in all other institutions and the consequent reinforcement of the marginalization processes it was initially supposed to eliminate. According to this view, the panacea would consist in a university of "diversified" elites made possible by the creation of parallel curricula. The proclaimed objective is only to reflect the population's diversity, and not promote equal opportunities for all.

7 Finally, since 1999 European universities have implemented new rationalization processes, such as the multiplication of quantifiable and "evaluable" criteria according to which a university's teaching and research activities are measured, classified, and 
financed, as well as the introduction of the search for "diversity" as a criterion of social justice. These two very different measures are both typical of the North American higher educational model and the result of a specific historical context.

\section{Neither an ideal nor a foil: the north american system of higher education in perspective}

Whether it is seen as an ideal or a foil, the North American system of higher education is often little known. It shall then prove most useful to begin this collection of articles with a reminder of its main characteristics. The first colleges - the present-day venerable Ivy League universities - were created in colonial America as private establishments designed to train the political and spiritual elites of the British colonies. The land's territorial division into thirteen relatively autonomous colonies explains the multiplication of such institutions which, after the fashion of Oxford and Cambridge, developed for their students a system of residential campuses. Following its independence, the young Republic recognized, through the 1787 Northwest Ordinance, the immediate social necessity of opening public teaching institutions in each of the newly created States. Even though the main objective at the time was to develop a system of public elementary schools, the double principle of the States' social responsibility regarding public elementary education and its usefulness to society was proclaimed from the start, before being extended to the educational system as a whole. A multiple system was soon established, including both private institutions and some financed by State subsidies. An important characteristic of education in the United States is that it comes under State, not federal authority.

9 The period from 1785 to 1860 was marked by extreme innovation and strong consumerism, with little supervision or regulation on the part of the federal State. This however did not bring about chaos, but the multiplication of institutions and increased disciplinary innovation. By 1860, the number of degree-granting institutions had thus risen from 25 to 241 nationally scale. Apart from new colleges, other types of institutions were also created during this period: universities proper, academies, seminars, scientific schools, normal schools, and institutes. Furthermore, the disciplines taught in colleges extended beyond the usual liberal arts - a mixture of Latin, Greek, mathematics, science, philosophy, and history, along with English composition and literature - to such fields as medicine, law, engineering, military science, commerce, theology, and agriculture.

\section{The mid- $19^{\text {th }}$ century and the birth of public and minority universities}

10 In the second half of the $19^{\text {th }}$ century, a dual phenomenon took place: the development of the web of higher education institutions, with the birth of new public universities and urban colleges and universities, on the one hand, and, on the other, the creation of institutions specially designed to provide access to higher education to groups that used to be excluded from it, most notably women and African-Americans.

11 The Morrill Act of 1862 was an important turning point, as it officialized the creation of what came to be known as "land-grant colleges", higher education institutions built on 
lands granted by the federated State for this very purpose. This act enabled the creation of the country's main public universities and thus represented a major landmark in the democratization of higher education, which became easily accessible both financially and geographically - to a great number of young men and women.

While land-grant colleges and State universities - thanks to their geographical proximity and reasonable cost - enabled the youth from many small towns and rural areas to at last have access to higher education, a similar trend appeared in largecities with the creation of municipal colleges and universities. ${ }^{8}$ The goal of these free and semi-free public institutions built in city centerswas to meet the needs of urban students, notably by offering innovative courses, such as advanced industrial techniques or commerce, - in addition to the more classical liberal arts. For the first time, urban center students who could not afford tuition as full-time students at a residential college could pursue still their studies while remaining in their parents' home and/or working a day job thanks to the development of evening classes and special arrangements for part-time students. Those very affordable urban colleges soon played a unique and indispensable role in the field of American higher education.

The access of women to higher education increased in the period following the Civil War, whereas it had previously been limited to the few rare "seminars" and "academies" that were open to them. The democratization process took two main forms: the creation of coordinate colleges, first of all, which were specific institutions separated from, yet linked to a corresponding male college - such as Radcliffe and Harvard, for instance, Barnard and Columbia, or Newcomb and Tulane, in Louisiana. Secondly, a movement for the development of coeducation was initiated. ${ }^{9}$ By the end of the $19^{\text {th }}$ century, nearly three quarters of the country's colleges and universities were open to women, even though the actual number of female students only represented $2.5 \%$ of the total number of young American women.

The struggle of women for access to higher education coincided with the early stages of the extension of educational opportunities to African-Americans. Before the Civil War, only 29 black students managed to graduate from a college or university. After the war, most initiatives were first of a charitable or religious nature. Around the turn of the century, a few philanthropic foundations created by corporations and wealthy private benefactors brought their support to the development of colleges for black people. Around 200 private or religious schools for black students were inaugurated in the 1870 s and 80 s, although the vast majority of the latter provided in fact nothing more than secondary education, thus compensating for the lack of high-schools for AfricanAmericans. Furthermore, these colleges and universities were often inadequately funded and therefore soon closed down. This situation foreshadowed a crucial problem regarding the access of African-Americans to higher education in segregated America, which involved the nature of the education provided and its adaptation to the actual level of schooling of young black men in the late $19^{\text {th }}$ century.

The original intention of the founders of black colleges was to provide the latter with the same kind of liberal arts education as white students. Black community leaders deemed that the country's future ministers, lawyers, doctors, political leaders, and businessmen had to acquire the same academic traditions as their white peers, and refused to consider the creation of a basic industrial and agricultural training as a realistic alternative. However, as a result of the near absence of elementary and secondary black public schools in the South, the number of black students was still very 
small. Only Howard University and Fisk University really did offer a classical liberal arts education of an academic level. In response to this situation, many philanthropists started advocating for a vocational type of education that would better suit the social realities and - very limited - economic possibilities of Africans-Americans in the South: the Tuskegee Institute, founded by Booker T. Washington in Alabama in 1881, is a perfect example of such initiatives. This very popular institution mainly provided agricultural training, and its prevailing philosophy inspired the creation of land-grant colleges for black students, an important number of which opened in the South after the 1896 Plessy v. Ferguson United States Supreme Court decision to uphold the constitutionality of State laws requiring segregation in public facilities under the "separate but equal" doctrine of "separate but equal": from then on, in order to keep black students out of their State schools and public universities, the Southern State governments hastened to open a number of separate colleges allegedly endowed with the same kind of resources as colleges for white people, and funds allocated on a "just and equitable" basis. For black students, however, the real situation was one of separation, and not of equal treatment and democratized higher education which largely remained an illusion until the Second World War.

Despite these important limitations, democratization was on its way for good. By the end of the $19^{\text {th }}$ century, two major factors restructured the world of higher education. First of all, the country's industrialization and fast-growing economy increased the importance of new technical and scientific knowledge in society. It was more and more understood that universities had to be modernized in order to meet the needs of the economic world. Secondly, the late $19^{\text {th }}$ century also saw the arrival in the United States of the German academic model, which was considered to be unequaled in Europe and which strongly emphasized the importance of scientific research. This popularity gave rise to the creation of a new kind of institution in American higher education: research "universities", in which professors were above all researchers whose independence had to be preserved, and which provided third cycle education, as opposed to the undergraduate education provided by simple colleges that offered no real research activities. It was mostly new urban establishments that were attracted by this model: Johns Hopkins University, for instance, strictly followed the German model and only offered postgraduate courses. Consequently, in the late $19^{\text {th }}$ and early $20^{\text {th }}$ centuries, American higher education started to be divided between a number of important research universities on the one hand, and, on the other, a dense network of institutions specialized in undergraduate liberal arts or semi-vocational education. This division continues today.

\section{The impact of the 1944 G.I. bill: massification and evaluation}

17 While democratization of higher education continued throughout the first half of the $20^{\text {th }}$ century, notably with the growing access of Jewish students who reached a significant number in the 1910s, notwithstanding tests and specific quotas, and women whose proportion in the total number of undergraduates rose above $47 \%$ by 1920 , the major turning point for democratization was the Servicemen's Readjustment Act of 1944, also known as the G.I. Bill. This Act guaranteed World War II veterans one year of free higher education for every period of three months spent in the army, up to a limit of 48 months. As part of this law, registration fees and other costs such as the purchase of books and school supplies were directly paid to the colleges or universities for a 
maximum amount of $\$ 500$ per year. At that time, tuition for private institutions added up to approximately $\$ 300$; tuition in State universities was considerably lower. Students were also granted a subsistence allowance. The law was an immediate success: as early as 1946, the number of GIs in universities rose above one million, and the Federal Government spent over $\$ 5.5$ billion. In 1950, out of the 14 million eligible veterans, over 2 million decided to go to college.

The G.I. Bill was a major innovation in the history of American higher education for several reasons. First of all, it made access to college an entitlement rather than a privilege. Consequentlythe number of beneficiaries waslimitless. Moreover, this entitlement was transferable to any college or university the veteran chose to attend: a veteran could choose to apply to Harvard, for example, but also in a community college close to his home, or in any school of law, medicine or business he wished to attend. In order to avoid abuse of the system, establishments had to be recognized by the Federal Government, which - as an indirect consequence of the G.I. Bill - gave rise to an evaluation system for universities. Because they wished to preserve their independence from the Federal Government - and notwithstanding the Tenth Amendment to the United States Constitution, which states that "the powers not delegated to the United States by the Constitution, nor prohibited by it to the States, are reserved to the States respectively, or to the people" -, the universities chose to voluntarily submit themselves to autonomous evaluation authorities. This marked the beginning of the regional accreditation system and its ten-year cycle of institutional evaluation, which gradually became standard procedure for all establishments awarding diplomas, especially when they wished to be granted Federal funds. Another change brought about by the G.I. Bill was the way in which universities and colleges evaluated the applications of prospective students: given the latter's recent increase, admissibility had to be determined as quickly as possible, which often proved to be difficult, as veterans generally could not present copies of grades, unlike other regular students. This gave rise to a system of admissions that came to rely more and more on standardized testing and tried to take into account all other experience outside of that acquired in high-school.

The G.I. Bill also led to several other major consequences, such as the expansion of universities, which had to be hastened in order to build new classrooms, housing, laboratories and sports amenities, and also to adapt the premises to the specific needs of sometimes disabled veteran students. Another striking effect of the G.I. Bill was the transformation of student culture under the influence of the massive arrival of these new troops: G.I. Bill students were often older than traditional students who were between 17 and 21 years old, and had a more pragmatic relationship to studies. As a result, universities quickly started diversifying their courses, so as to provide the new students with a training that would quickly enable them to find good jobs in the context of the expanding post-war economy. The arrival of G.I. Bill students also led to the masculinization of campuses - even though around 60000 women veterans were included among the Bill's beneficiaries -, which somewhat went back on the advances accomplished in this field over the preceding decades: not until the 1970s would women again represent $40 \%$ of the country's undergraduate students - a figure amounting to $55 \%$ today.

The considerable impact of the G.I. Bill should not be exaggerated, however, as it also implied a crucial limit regarding the weakness of its influence on race relations in 
colleges and universities. Of course, African-American G.I.s were also eligible and the number of black students clearly increased thanks to these measures, but the law made no mention of the obligation of non-discrimination for participating institutions. Consequently, the establishments that traditionally excluded racial minorities could keep doing so with total impunity - especially as the Federal Government itself had practiced segregation among its armed forces until 1948. Despite the amount of democratic progress which the G.I. Bill gave rise to, the "separate but equal" doctrine still governed racial relations in the United States, in universities as well as other institutions. This situation lasted until the Civil Rights Act of 1964, which eventually outlawed segregation and discrimination - both of which were still practiced, notwithstanding the Supreme Court Brown v. Board of Education decision made in Topeka, Kansas, 1954.

This being said, the G.I. Bill may be seen as the first stage in the evolution of the new role played by the Federal Government in the field of higher education, an evolution that still goes on today. As early as 1947, president Harry Truman charged his Commission on Higher Education to establish a report - published under the title of Higher Education for American Democracy - which underlined the national importance of higher education in the new context of the Cold War, as much from a social point of view as regarding the United States' worldwide influence and power of defense. Sixtyfive years later, this perspective has not really changed at all - it is even more strongly adopted, reinforced as it has been by the spectacular growth of American universities ever since World War II.

Following the Second World War, American higher education benefited from thirty glorious years of prosperity, prestige and popularity. The Federal Government pursued its scientific research financing policy, which was recognized of strategic importance and initiated with the Manhattan project, a research and development project that produced the first atomic bombs during the war. The Federal Government started financing research and training programs carried out in foreign languages and over various cultural areas, and signed a number of research contracts with an important group of American universities to which it appointed specific missions of applied research. It must be specified that such federal funds in no way replaced the financial contribution provided by the federated States, which remained the chief governmental authority regarding matters of education at all levels. However, the fact remains that federal financing soon became indispensable for the functioning, expansion and reputation of these establishments, and that the vast majority of colleges and universities that did not benefit from such financing were obliged to find other sources of financing and other means of distinguishing themselves from the establishments with which they competed to attract an ever-growing number of students more and more desirous of finding a university that fitted their personal interests and needs. Apart from offering an unprecedented level of financing in the history of higher education, this new implication of the Federal Government also led to an increase in the degree of competition among the various establishments, which consequently had to develop a unique niche and identity.

23 Concurrently to the financing of research for reasons of national interest, the Federal Government acknowledged the double necessity of extending higher education to a greater portion of the population - thanks to the creation of scholarships through the Higher Education Act of 1965 -, and opening establishments endowed with an 
international reputation of excellence in research and training. The pre-war academic landscape was even further enriched by the multiplication of community colleges local establishments offering semi-professional training at a reasonable cost -, which contributed to the enlargement of the system's basis while the top levels of the pyramid kept rising higher and higher thanks to the confirmed capacity of colleges and universities to provide advanced and selective programs at all levels, selection being presented as a guarantee of quality. The same period also witnessed the emergence of a new type of institution: private profit-making establishments offering specialized or professional training courses, and corporate universities created by big companies.

This golden age based on the democratization of higher education and the power of research universities still underlies the current reputation of the American higher education model. Another important factor might also have been the system's great adaptability to a double challenge of massification caused by the Baby Boom - the number of students rose from under 1.5 million before World War II to 7.9 million in 1970 - and the demands of the identity movements of the 1960s and 70s - especially those emanating from ethno-racial and sexual minorities -, which deeply transformed academic institutions.

In fact, the structures of American higher education have little evolved since the 1970s, even if the economic crisis of 2008 has given rise to new challenges. The crisis has considerably reduced the resources devoted to higher education - and education in general - in the budgets of the Federal State and federated States alike, while concomitantly triggering off an increase in registration fees that has placed higher education out of reach for a growing portion of the population. This hazardous questioning of several decades of democratized higher education now raises a hitherto unimaginable question regarding the limits and durability of the American model. It is in such a context that one should interpret president Obama's recent call for the revival of American higher education by banking on community colleges rather than relying on the excellence of elite establishments. ${ }^{10}$

In a country where the student population attained 19.1 million people in 2010 - as opposed to 13.8 million in 1990 , and which now represents over $41 \%$ of the $18-24$ yearolds - divided among some 4352 establishments, and where the cost of studies has more than doubled since 1990 - in 2010, the average annual cost of registration fees and housing for State students in public colleges and universities was a little below 15000 \$, as opposed to 40000 in private establishments -, the advantages of this reorientation of national priorities clearly appear, and deserve to be reflected on in other contexts as well.

Paradoxically, the implementation of standardized systems of evaluation dates back to 1945 and the G.I. Bill, which was an important lever for the democratization of the system, as the rationalization of the latter soon became essential to deal with its numerical increase and control the circulation of public funds. In fact, the North American system of higher education is fundamentally multi-tiered and relies on the multiplication of specialized institutions - whether at the university or the department level - in order to incorporate different sectors of the population. The readers of this collection of essays will thus be able to understand the development of Black Studies departments in the 1960s thanks to Caroline Rolland's article, whereas Ramón Grosfoguel analyzes the contemporary dilemmas at work in the departments of Ethnic Studies. Such dilemmas are largely shared by the indigenous universities of Mexico (as 
seen in David Lehmann's articles) and Bolivia (as seen in the article of Anders Burman), although they stem from a different academic history, the roots of which plunge deep into Medieval Spain.

\section{At the crossroads of europe and the united states: the latin american model of higher education}

As a means of comparison with the North American process, a few historical landmarks must first be defined. ${ }^{11}$ Certain specialized institutions for the intellectual education of elites are mentioned in the sources pertaining to the Aztec and Inca Empires prior to 1492. The Spanish conquest imported and disseminated an adapted version of the Spanish model of medieval scholastic Universities, typified by those of Salamanca (Studium Generale, 1218) and Alcala de Henares (Estudio de escuelas generales, 1293). Courses were first taught in the cloister of the cathedral or in some rented house in the city, but in the early $\mathrm{XV}^{\text {th }}$ century, colegios were built - buildings that included a boarding school for poor students and grant holders, as well as classrooms and areas devoted to social, cultural and sports activities. Colegios menores prepared students to bachiller and colegios mayores taught degree and doctorate classes, but the tests were taken at the University itself. However, colegios were gradually monopolized by the nobility. The influence of Salamanca, for instance, could be perceived in Lima (1575) and Mexico (1595), through the adoption of its organizational modalities, programs, practices, privileges and the circulation of teachers. Lima and Mexico were engaged in a kind of competition for influence over other regional establishments. Most universities received both royal and pontifical authorizations. They were usually built against seminaries, convents, or colleges of Dominicans, Augustinians or Jesuits. ${ }^{12}$ Certain universities described as mayores, oficiales and generales received annuities from the real hacienda and benefited from many Chairs and privileges. The others were termed as particulares and were not even entitled to deliver diplomas. There existed four different facultades mayores (major faculties) teaching theology, canon law, law and medicine, and one minor faculty devoted to "Art and Philosophy." A colegio run by Franciscans - Santa Cruz de Tlatelolco - was created as early as 1533 for the indigenous elites of Mexico: for a period of approximately 50 years, the teaching of Latin and the invention of a Latin alphabet adapted to Nahuatl gave rise to a number of important scientific works based on medical and historical Nahua knowledge. The first generations of natives who came out of this college were given important responsibilities in their own universities and other colonial institutions, before this model finally collapsed. Even though this diffusionist model - which lays emphasis on the importation of the Spanish medieval model - is somewhat over-simplistic, it nevertheless demonstrates an important fact: the fast and lasting foundation of over 25 universities spread out over the Spanish American territory, whereas the Portuguese Crown, at the same period of time, only allowed the creation of colleges - there was consequently no university on Brazilian soil until the royal family settled there in 1808 . 
Mailboxes of the departments of the faculty of Philosophy, National University of Asunción

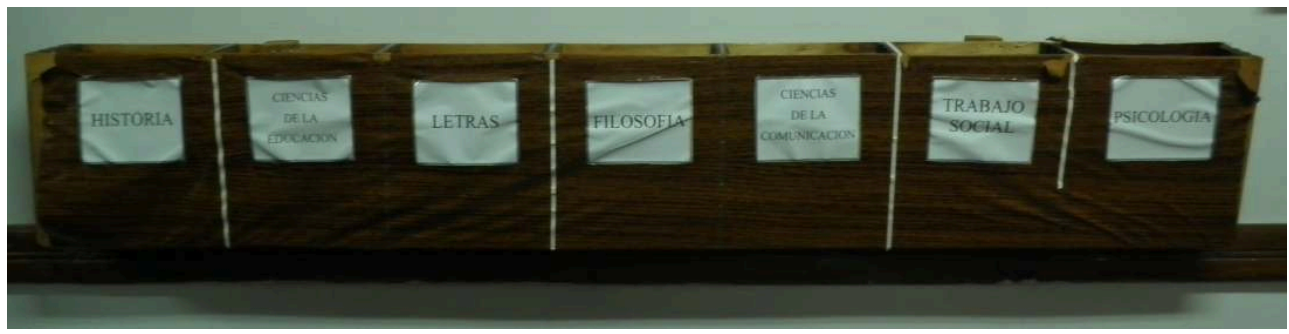

A concrete aspect of the history of knowledge construction: the mailboxes of the seven departments of the faculty of Philosophy at the National University of Asunción.

Photo: C. Boidin, Paraguay 2011

By the end of the colonial period, a strong current coming from France influenced Latin American universities, just before the period of Republican independences witnessed a dissemination of the Napoleonic organization principles - characterized by long professional careers of 6 and 7 years with no intermediate diplomas - and the Humboldtian principle of the unity of teaching and research. Comtian Positivism also had an important impact, both in the Spanish and Portuguese territories. In the $20^{\text {th }}$ century - as explained in Guadalupe Olivier's article - there were three crucial milestones: first of all the Cordoba reform of 1918, that defended the principle of free education and the struggle for the democratization of an institution defined as public and autonomous. Secondly, the reform in the 1970s led to the multiplication of greatly differentiated higher educational institutions which, though not universities per se, played a role in opening up the public system. The third reform is still ongoing since the 1990s, and has led to the acceleration of the massification, privatization and internationalization of Latin American higher education. 
The multiplication of commercials for private Universities in Latin America.

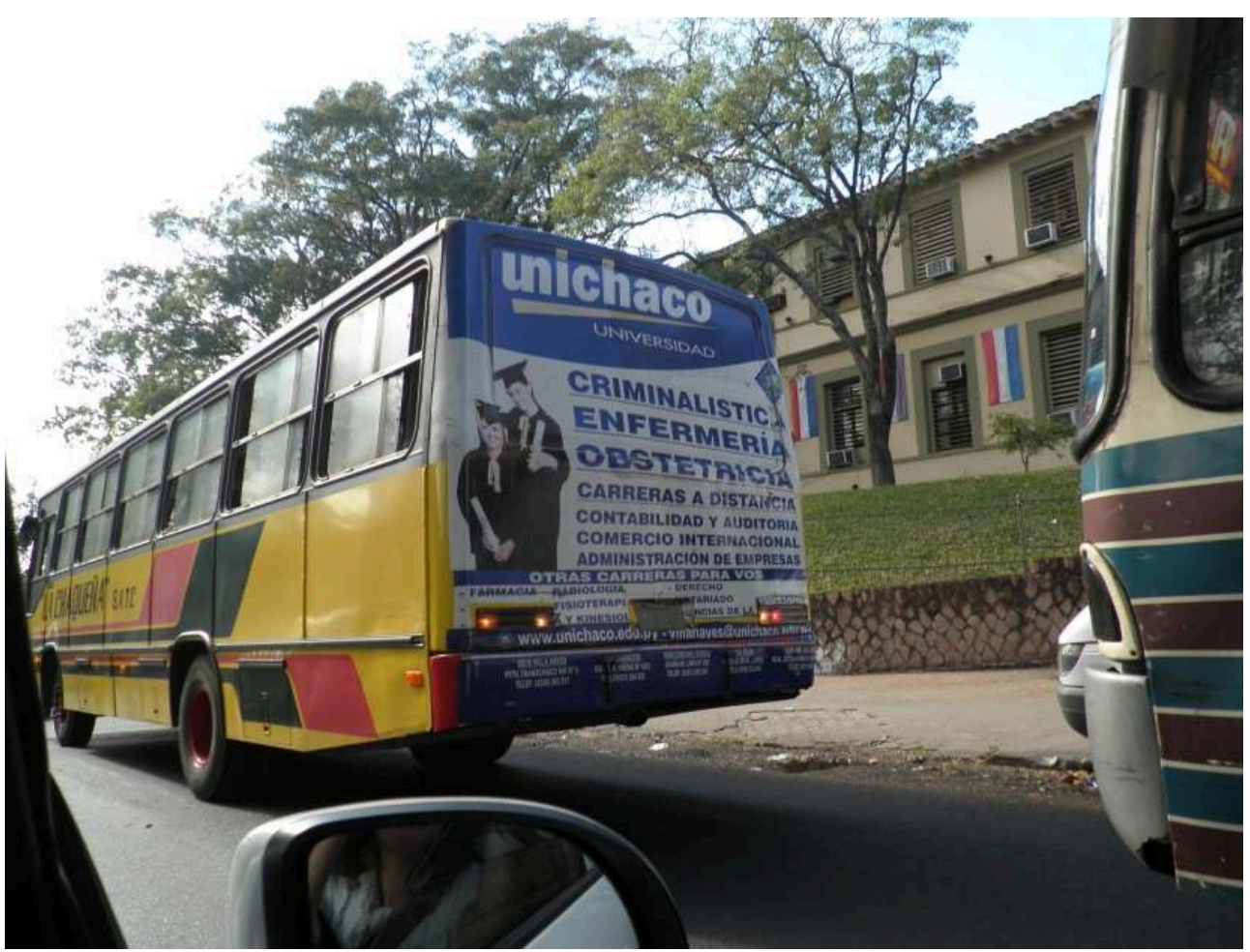

ASUnción, PARAgUaY, 2011.

PHOTO: C. BOIDIN 2011

\section{The massification, privatization and development of indigenous universities in latin american higher education}

There are two diverging types of analyses regarding the matter: one is based on a long tradition of critical thinking in Latin America and consists in decyphering contemporary Neoliberal policies, ${ }^{13}$ whereas the other gives rise to a proliferation of synthetic reports meant to justify a number of "recommendations" in the field of reforms - World Bank and International Monetary Fund in particular. But before we go any further, we should examine a few figures concerning the fast-growing massification and privatization of the Latin American higher education system: ${ }^{14}$

Satistics: institutions and students registered in the igher education system in Latin America

31 Number of universities and institutions of higher education (IHE) in Latin America

195075 Universities

1975330 Universities

1985450 Universities

1995812 Universities (60,7\% private) $5438 \mathrm{IHE}$

20021213 Universities (69,2\% private) $7514 \mathrm{IHE}$

Today : probably over 2000 Universities.

Number of students registered in the higher education system in Latin America

$1950 \quad 267000$ 
19701640000

19804930000

19907350000

200011500000

200515293181

200917757000

Today (2012) : around 18 million.

Brazil now has 5.95 million registered students, ${ }^{15}$ Mexico and Argentina around 2.5 million each: all three figures add up to a total of approximately 11 million, which represents $60 \%$ of the 18 million Latin American students on the continent to this day. These three countries also concentrate the highest number of Master's/Doctorate degree students. Regarding the total number of students, the next most important figures are found in Colombia (1.3 million), Venezuela (1 million), Peru (900 000), Chili (670 000), Cuba (470 000) and Bolivia (350 000). The registration rate in Latin American higher education has considerably improved, moving up from $17 \%$ in the early 1990 s to $34 \%$ today, with considerable gaps between the different countries: $18 \%$ in Guatemala, $27 \%$ in Mexico, $30 \%$ in Brazil, 32\% in Colombia, 35\% in Peru, 52\% in Venezuela, $67 \%$ in Argentina, and up to $88 \%$ in Cuba. In other words, considering that Mexico and Argentina have the same number of students, Mexico is far from meeting its population's expectations as well as Argentina does. Furthermore, certain education systems are particularly unequal, as they cause low-income families to be excluded from quality public universities, not having sent their children to good secondary schools, whether private or public: this is particularly the case in Brazil, Mexico, Chile and Ecuador. The Latin American annual global investment per student is now of 2380 $\$$. Put differently, even though there are about as many students in Latin America as in the United States - 18 million as opposed to 19 -, the former receive considerably less financial aid than the latter - and one must remember that registration fees in the United States may range from 15000 to 40000 \$ a year.

This massification - that some will call democratization - could not have happened without the multiplication of private universities, whether non-profit or blatantly attracted by the education investments that a growing number of Latin American families are willing to make for their children. The integration process of the Americas is giving rise to the creation of certain associations between the higher education institutions of several countries, both public and private - see Guadalupe Olivier's article $^{16}-$, and the multiplication of comparative reports. 
An advertisement for a University on one side, and for a "Knowledge Institute" on the other, San Lorenzo, Paraguay.

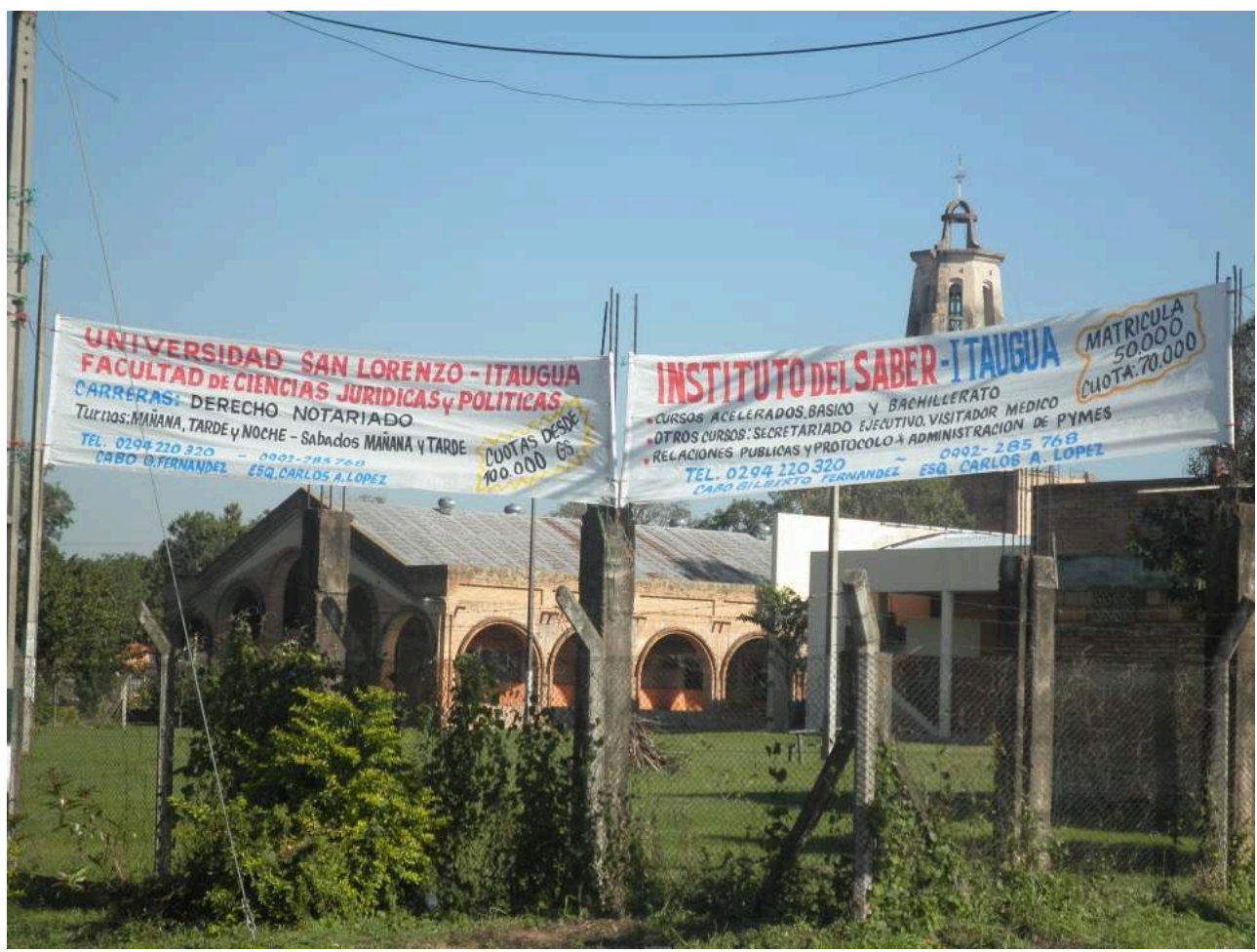

Photo: C. Boidin 2011

Since the 1960s, a number of comparative studies of the Latin American education systems have been carried out on the request of several organizations from the UNESCO and the CEPAL (Comisión Económica para América Latina y el Caribe). From 1978, the Centro Regional para la Educación Superior en América Latina y el Caribe (CRESALC) - transformed in the late 1990s into the Instituto Internacional para la Educación Superior en América Latina y el Caribe (IESALC) - has released many reports, such as El Documento de Política para el Cambio y el Desarrollo de la Educación Superior (1995), which in 1998 led the UNESCO to define an action plan organized around five priorities: 1) the social relevance of provided teachings, 2) quality and evaluation, 3) management and financing, 4) the use of new means of communication, 5) international cooperation. These criteria might remind one of those defined by the European Union in 1998, with the slight difference that the social dimension of education is here presented as a stronger priority than the necessity of evaluation.

37 Finally, a few years before the creation of the European Community, several Latin American countries greatly liberalized their higher education systems and implemented standardized systems of teaching and research evaluation, but nevertheless multiplied the opening of institutions mainly intended for indigenous populations: to wit, the "indigenous" - also called "intercultural", depending on the countries and periods - universities, regarding which Anders Burman (for Bolivia) and David Lehmann (for Mexico) provide some insight in their articles. 


\section{Deprovincializing european universities}

to a series of massive demonstrations led by protesters from both the left and right wings. The desire to defend a certain idea of scientific knowledge and higher education as "collective and public goods" - as opposed to "individual consumer goods," namely, a useful and valuable diploma in an individual's career - brought together a great number of fields such as human and social sciences, law, mathematics, physical and natural sciences. The shift from a pedagogical to a mercantile relationship - in which the student became a mere customer - went against the fundamental notions of European academic culture. However, public opinion sometimes interpreted this defense as the refusal on the part of academics to prepare their students for the professional world, even if this wave of protest in no way rose from such intentions: a rigorous training undoubtedly sharpens the students' critical reasoning and increases their autonomy, thereby preparing them for an intelligent adaptation to any social and professional - situation. The protest really resulted from a refusal of the importation of an entrepreneurial culture into universities, and the transformation of the latter in corporate businesses.

This series of misunderstandings and confusions finally led us to wonder if the crisis of French - and, more broadly, European - universities did not really stem from more profound causes than the mere pressure exerted by the Bologna process: that is, a general loss of impetus of the academic model and the universalism of Enlightenment. As a matter of fact, inside criticism of knowledge and the relation to knowledge established in universities is no novelty - if one considers the works of Foucault, Bourdieu, Lyotard, Latour, Rancière and others... Over the last ten years however, the Kantian-Humboldtian academic model - "science by and for science," disregarding theology ; the encyclopedic nature of research; the figures of the teacher-researcher and student-researcher - has also been widely questioned and criticized by Asian, Latin American, North American and European postcolonial thinkers. More particularly, certain Latin American authors - who would rather define themselves as "decolonial" than "postcolonial," - question the epistemic Eurocentrism that lurks behind certain institutional practices. They denounce the epistemic eurocentrism, racism and sexism present in institutions where only ideas resulting from Western traditions and published by European - or Euro-American - men are considered as potentially universal. More profoundly, these authors question the idea of total encyclopedic - and above all anthropological - knowledge which, although it is an approach to knowing "others," does not lead to their full recognition as subjects and authors. In fact, such criticism does not necessarily give rise to a narrow-minded kind of relativism and the abandon of all universal research. On the contrary, these reflections are interesting as they underline the necessity of starting a process of universal thinking through a dialogue held between researchers from various epistemic backgrounds.

The proposed reforms of the Bologna process do not answer such in-depth critical analysis. On the contrary, by focusing essentially on the methods for managing and evaluating teachers and diplomas, they further reinforce the disenchantment in the academic world - despite the great potential for renewal of French and European universities. It might prove worthwhile, for example, to engage more firmly in a number of interepistemic debates, with the aim of inventing a new ecology of 
knowledge. Far from being restricted to a kind of flabby relativism - for lack of anything better - and "trivial stories", the real objective would be to look for universal knowledge via the organization of horizontal dialogues between various traditions of thought. Reforming the academic system by trying to create a less provincial and more open type of universalism implies a total reworking of our ways of thinking and dividing disciplines. The creation of the Campus Condorcet, for instance, could present the opportunity of seeking pluriversal thought-forms while keeping in contact with the issues at stake in society, ${ }^{17}$ which would give rise to a number of openings and new knowledge constructions already apparent in the Campus' specific choice of architecture. The conversations with Cynthia Ghorra-Gobin and João Sette Whiteker Ferreira regarding the organization of - respectively - Californian and Brazilian campuses will enable one - by contrast - to grasp the specificities of a campus set in the North of "Grand Paris", and therefore opened to rapidly-changing working-class areas such as Aubervilliers and Saint Denis.

For this reason, the present collection of articles - and the campus conversation that goes along with it - will try to start a dialogue with other traditions of thought - Latin American especially - and other experiences such as Latin American indigenous universities. As a matter of fact, when the corporate universities of the United States became a model in the 1970s, Latin American countries rapidly adopted this model and multiplied the creation of this kind of universities in the 1980s, while also enabling a number of autonomous and indigenous universities to come into existence. In other words, the analysis and questioning of the academic transformations at work over the last four decades on the American continent and over the last ten years in Europe, should help us to better understand our present situation in order to invent the European universities of tomorrow.

\section{NOTES}

1. We are here borrowing Dipesh Chakrabarty's phrase "provincializing Europe" in Provincializing Europe - Postcolonial Thought and Historical Difference(Princeton: Princeton University Press, 2000). For Dipesh Chakrabarty, who mostly focuses on the Indian situation, "European thought is at once both indispensable and inadequate in helping us to think through the experiences of political modernity in non-Western nations, and provincializing Europe becomes the task of exploring how this thought - which is now everybody's heritage and which affects us all - may be renewed from and for the margins. But, of course, the margins are as plural and diverse as the centers." (p. 16) For we who think from a European perspective, deprovincializing European universities amounts to humbly recognizing the vital necessity of "plugging ourselves in" and letting ourselves be renewed by the widest possible diversity of traditions of thought. We shall come back to this at the end of this presentation.

2. For a recent ranking of Latin American universities, see: http://americalatina.blog.lemonde.fr/2011/10/05/l'universite-de-sao-paulo-en-tete-du-premier-classementlatino-americain/ 
3. http://www.cpihts.com/PDF/Declaracao\%20de\%20la\%20Sorbonne.pdf (website visited on June 2 2012)

4. http://eacea.ec.europa.eu/education/eurydice/documents/thematic_reports/122FR.pdf

5. Isabelle Bruno, "Y a-t-il un pilote dans l'Union ? Tableaux de bord, indicateurs, cibles chiffrées : les balises de la décision," Politix, Vol. 82, 2, 2008, p. 95-118.

6. http://www.eqar.eu/uploads/media/London-Communique-18May2007.pdf

7. The common frame of reference includes the generalized use of the three-stage division three stages (bachelor's degree, master's degree, and $\mathrm{PhD}$ ) in every higher educational programme, and the capitalization of ECTS throughout a student's studies regardless of his/her university and region.

8. This was not an entirely new trend, as the Free University of New York City, for example, was founded in 1847. However, the post-Civil War period witnessed an acceleration in this trend, with the birth of the University of Cincinnati, Hunter College in New York, Wayne University in Detroit, Boston University, Temple University in Philadelphia, and George Washington University in Washington, D.C.

9. The newly created public universities played a pioneer role in this movement: : the University of Iowa, first of all, as early as 1855, the University of Wisconsin in 1863, followed by the Universities of Indiana, Missouri, Michigan and California in the 1870s. Following that decade, most Western and Midwestern higher educational institutions had accepted coeducation, and remaining resistance was mainly concentrated in Northeastern Ivy League universities.

10. As Dominique Godrèche rightfully puts it: "being accessible to all, regardless of age, social distinction or academic origin, community colleges in the United States are a remedy to an expensive and all too selective system of higher education. They offer a post-high school twoyear curriculum preparing students to an associate's degree that will later on enable them to be awarded a bachelor's degree, after two more years in a university. Community colleges thus give access to higher education to students from underprivileged backgrounds, who could not finance a four-year cycle in a private university. Moreover, these colleges provide professional training courses sanctioned by certificates, along with a diversified education, to a category of the population that would normally be entitled to nothing - notably immigrants. [...] Community colleges present a number of important assets, such as their integration in their region's economic and social fabric, and their reactivity and adaptability to new needs." See Dominique Godrèche, "En marge des universités, les community colleges" and "Onze millions d'étudiants", Le Monde diplomatique, June 2010.

11. For a first approach, see Celina Lértora Mendoza, "Lineamientos para una historia de la universidad latinoamericana," Cuadernos de la Facultad de Humanidades y Ciencias Sociales, diciembre, $n^{\circ} 15$, pp.43-51. For some further insight, see Diana Soto Arango, Manuel Lucena Salmoral y Carlos Rincón (dir.), Estudios sobre la universidad latinoamericana. De la colonia al siglo XXI, RUDECOLOMBIA, HISULA, Universidad Pedagógica y tecnológica de Colombia, Ed. Doce Calles, 2003. 12. See Aguedas Rodriguez Cruz, la proyeccion de la universidad de salamanca en Hispanoamérica, no date (published after 2000), consulted on http://www.americanistas.es/biblo/textos/s04/ s-04-10.pdf ; La Universidad en la América hispánica, Madrid, Mapfre, 1992.

13. See the works of Mollis, M. (comp.), Las universidades en América latina : reformadas o alteradas?, Buenos Aires, CLACSO, 2003.

14. Francisco Lopez Segrera, "La educacion superior en el mundo y en América latina y el Caribe”, Revista paraguaya de sociologia, year 47, $n^{\circ} 136$, january-june 2010. Lopez Segrera is one of the main references thanks to his UNESCO reports on higher education in Latin America since the year 2000. All quoted figures are taken from his article, unless otherwise mentioned.

15. http://gestao2010.mec.gov.br/indicadores/chart_60.php (according to Brazilian Ministry of Higher Education). 
16. http://america-latina.blog.lemonde.fr/2011/10/05/l'universite-de-sao-paulo-en-tete-dupremier-classement-latino-americain/

17. These principles are presented in the scientific program of the Campus as follows: "Bringing together the humanities and social sciences; associating the study of the past with that of the present; promoting transversal questioning adapted to the dynamic analyses of a global world. These principles follow a double orientation: towards objects - cultural areas, religions, texts, territories, populations etc. - rather than disciplines; and towards the creation of a tool of expertise and analysis with which to tackle the issues of the contemporary world, associated with the broadening and renewal of prospects in the realm of human and social sciences." http:// www.campus-condorcet.fr/campus-condorcet/La-politique-scientifique/Le-programmescientifique/p-451-Le-programme-scientifique.htm

\section{AUTHORS}

\section{CAROLINE ROLLAND-DIAMOND}

Maître de conférences en histoire à l'Université Paris Ouest Nanterre. Ses axes de recherche portent sur l'histoire sociale, l'histoire politique et l'histoire urbaine des États-Unis au XXe siècle, ainsi que sur l'histoire des mouvements étudiants américains depuis les années 1960, l'histoire de l'institution universitaire, la théorie des mouvements sociaux et l'histoire de la répression politique. Elle est l'auteur de Chicago : le moment 68 . Territoires de la contestation étudiante et répression politique (Paris: Syllepse, 2011) et a co-dirigé (avec Robi Morder) Etudiant(e)s du monde en mouvement. Migrations. Cosmopolitisme et internationales étudiantes (Paris, Syllepse, 2012).rolland.caroline@gmail.com

\section{CAPUCINE BOIDIN}

Maître de conférences en anthropologie à l'Université Sorbonne Nouvelle Paris 3, IHEAL (Institut des Hautes Etudes d'Amérique Latine). Chargée de cours de guarani à l'INALCO (Institut National des Langues et Civilisations Orientales), ses axes de recherche portent sur le métissage, le genre, les mémoires de guerre. Elle a publié en 2010 un numéro des Cahiers des Amériques latines sur le tournant décolonial.

http://www.ladocumentationfrancaise.fr/catalogue/3303332400621/index.shtml; http:// www.iheal.univ-paris3.fr/spip.php?article1041

\section{JAMES COHEN}

Professeur à l'Institut du monde anglophone et enseignant à l'Institut des hautes études de l'Amérique Latine, Université de Paris 3 Sorbonne Nouvelle. Spécialiste des questions de race/ ethnicité et d'immigration aux Etats-Unis et du rôle des Etats-Unis dans les Amériques. jim.cohen@libertysurf.fr

\section{RAMON GROSFOGUEL}

Maître de conférences (Associate Professor) en études ethniques à l'université de Californie, Berkeley et chercheur invité auprès de la Maison des sciences de l'homme à Paris. Il a publié de 
nombreux articles et ouvrages sur l'économie politique du système mondial et sur les migrations caribéennes en Europe occidentale et aux États-Unis. Grosfogu@Berkeley.edu 